\title{
The Influence of Open-Ended Approach to Mathematical Creative Thinking Ability of 5th Grade Students Elementary School in Padang
}

\author{
$1^{\text {st }}$ Ranny Rasyidah Sabrina \\ Department of Elementary FIP \\ Universitas Negeri Padang \\ Padang, Indonesia \\ rannyrasyidah1993@gmail.com
}

\author{
$2^{\text {nd }}$ Mega Iswari \\ Jurusan PLB FIP \\ Universitas Negeri Padang \\ Padang, Indonesia \\ mega_iswari@yahoo.com
}

\author{
$3^{\text {rd }}$ Yerizon \\ Mathematics and Science Faculty \\ Universitas Negeri Padang \\ Padang, Indonesia \\ yerizon@yahoo.com
}

\begin{abstract}
Mathematical creative thinking ability of elementary school students in Padang is still low. This is due, among other things, to the learning that is still dominated by the teacher, students are still focused on the way taught by the teacher and have not been able to solve the problem properly and creatively. To overcome this problem, learning process is used through an open-ended approach. This study aims to determine the effect of the open-ended approach on students' mathematical creative thinking skills. This type of research is quasi-experiment. The population of this study is all students of grade $\mathrm{V}$ elementary school in Padang city, registered in group IV Padang Timur sub-district in the first semester of the academic year 2017/2018. Sample selection is done by random sampling. The experimental class is VA class students at SD Negeri 23 Marapalam and as a control class are fifth-grade students of SD Negeri 20 Air Camar, Padang city. The research instrument is a prior ability test and a test in the form of mathematical creative thinking skills. Data analysis was carried out using two-way t-test and ANAVA for interaction. The results of the analysis show that: (1) students' creative thinking ability taught with the open-ended approach is better than students taught with conventional learning. (2) The ability to think creatively of high and low students taught with an open-ended approach is better than students taught with conventional learning. (3) There is no interaction between learning through an open-ended approach and prior ability to students'mathematical creative thinking abilities.
\end{abstract}

Keywords: open-ended approach, mathematical creative thinking.

\section{INTRODUCTION}

Mathematics as one of the subjects taught at school that has several important uses for students. Mathematics needs to be given to all students from elementary school to college to equip them with the ability to think logically, analytically, systematically, critically and creatively as well as the ability to work together. Susan [1] revealed that mathematics is one of the disciplines that can improve thinking skills and contribute to solving everyday problems and in the world of work, as well as providing support in developing knowledge. Mathematics learning is a teaching and learning process that is built by the teacher to develop students 'thinking creativity that can improve students' thinking skills, and can improve the ability to construct new knowledge as an effort to improve good mastery of the mathematical material. Mathematical learning has a function as a means to develop the ability to think critically, logically, creatively, and work together as needed by students in modern life. Mathematical learning has an important contribution to the development of the ability to think creatively in each individual student in order to become a quality human resource.

Torrance in Filsaime [2] states that creative thinking is a process that involves elements of originality, fluency, flexibility, and elaboration. It was further stated that creative thinking is a process of being sensitive or aware of problems, deficiencies, and gaps in knowledge for which no solution is learned, bringing along information from the memory warehouse or external sources, defining difficulty or identify missing elements, find solutions, suspect, create alternatives to solve problems, test and retest these alternatives, perfect them and finally communicate the results.

In fact, students'mathematical creative thinking ability is still far from what they expected. The Ministry of Education and Culture released the achievement of the Program for International Student Assessment (PISA) value, Tuesday 6 December 2016 together with 72 countries participating in the PISA survey. The results of this 2015 survey of a total of 76 countries and regions that entered the PISA survey, Indonesia ranked 69th. Indonesia's weaknesses in PISA implementation included (1) Students had difficulty working on questions that required problem-solving, argumentation and communication skills, (2) Students leave work on questions that have long information, and tend to be interested in routine questions related to formulas. Based on the results of the International Valuation Survey, it is known that students' mathematical abilities in Indonesia are still low compared to other countries.

The Open-Ended Approach is a mathematics learning approach that can help develop creative activities and mathematical mindset and provide opportunities for students to investigate various strategies and ways that they believe in accordance with their elaboration abilities. The use of the Open-Ended approach as an approach that is able to overcome the problem of mathematical creative thinking is also shown from the many researches on this subject, including in Japan, Munroe [3]; in Thailand, Inparashita [4]; in Indonesia, Murni, [5]; Riyanti, [6]; Fatah, [7]; and Irawan [8]; in Jordan, Al-Absy [9]; and in Portugal Viseu [10]. The results show how the Open-Ended approach can be used to overcome students' mathematical problems. The Open- 
Ended approach can be one solution to overcome student learning difficulties.

Learning with open-ended approach is seen from the strategy of how the subject matter is delivered, namely in the process of giving a problem to students where the answer or solution is more than one. This is in accordance with Shimada's opinion [11] that learning with an open-ended approach is a learning approach that presents a problem that has more than one answer or solution. Nohda in Suherman [12] states that the purpose of open-ended problem learning is to help develop students' creative activities and mathematical mindset through simultaneous problemsolving. In other words, creative activities and students' mathematical mindset must be developed to the maximum extent possible according to the ability of each student.

The open-ended approach gives students the opportunity to investigate various strategies and ways that they believe in accordance with the ability to elaborate on problems. The aim is that students' mathematical thinking skills can develop optimally and at the same time the creative activities of each student are communicated through the learning process. Guided by the theory, a learning approach is needed that provides opportunities for students to use their understanding in answering math problems, not only memorizing formulas so that student learning outcomes in mathematics learning can be improved. One solution that can be used to overcome the problem of low student learning outcomes related to mathematical creative thinking ability is by using open-ended problem approaches in mathematics learning.

Learning with an open-ended approach can provide opportunities for students to gain knowledge/experience of finding, recognizing, and solving problems with several techniques. Learning by using open-ended approaches can improve students' creative thinking skills.

The questions in this study are stated as follows: (1) Is students creative thinking ability who follow learning with an open-ended approach better than those using conventional approaches? (2) Is the creative thinking ability of students with high prior abilities who follow learning with an openended approach better than those using conventional approaches? (3) Is the ability to think creatively in lowability students who follow learning with an open-ended approach better than those using conventional approaches? (4) Is there any interaction between learning through an open-ended approach and prior ability to students'mathematical creative thinking abilities.

\section{METHODS}

This study uses a quantitative approach in the form of quasi-experimental design which aims to compare the effect of open-ended approaches with conventional approaches on students' mathematical creative thinking skills. The variables involved in this study are learning with an open-ended approach and conventional approaches as independent variables, the ability to think mathematically as the dependent, and the prior ability as a moderator. The study was conducted on fifth-grade students of SDN gugus IV in Padang Timur District who have the same curriculum and KKM. From each school, two classes from 10 classes were randomly selected as research samples. 30 students of SDN 23 Marapalam who attended learning with an open-ended approach and 30 students of SD C 20 Air Camar who followed conventional learning.

This research data was collected using tests. Tests are used to measure students' creative thinking skills. The test was validated by experts, then tested to meet the criteria for validity and repayment. Indicators of students' mathematical creative thinking skills are (1) fluency, (2) flexibility (flexibility), (3) original (originality), (4) elaboration (elaboration). The students' mathematical creative thinking skills are seen from the pretest and posttest. Furthermore, the data were analyzed using two-way t-test and Anava after conducting a series of normality and homogeneity tests.

\section{RESULTS AND DISCUSSION}

Based on the results of data analysis of mathematical creative thinking abilities of students who followed learning with open-ended and conventional approaches can be seen in table 1 .

TABlE1. Data on Mathematical Creative Thinking Ability EXPERIMENTS AND CONTROL CLASS

\begin{tabular}{|c|c|c|c|c|}
\hline Classes & Prior Ability & Result & & \\
\hline \multirow{6}{*}{ Experiment } & \multirow{2}{*}{ High } & Pretest & 7,27 & \multirow{2}{*}{0,71} \\
\hline & & Posttest & 9,20 & \\
\hline & \multirow{2}{*}{ Low } & Pretest & 5,40 & \multirow{2}{*}{0,57} \\
\hline & & Posttest & 8,20 & \\
\hline & \multirow{2}{*}{ All } & Pretest & 6,33 & \multirow{2}{*}{0,64} \\
\hline & & Posttest & 8,70 & \\
\hline \multirow{6}{*}{ Control } & \multirow{2}{*}{ High } & Pretest & 7,43 & \multirow{2}{*}{0,46} \\
\hline & & Posttest & 8,50 & \\
\hline & \multirow{2}{*}{ Low } & Pretest & 5,44 & \multirow{2}{*}{0,40} \\
\hline & & Posttest & 7,19 & \\
\hline & \multirow{2}{*}{ All } & Pretest & 6,37 & \multirow{2}{*}{0,43} \\
\hline & & Posttest & 0,43 & \\
\hline
\end{tabular}

From the table above it can be seen that the average creative thinking ability of students who use the open-ended approach is higher than students who use conventional learning, seen from the prior ability of high, low or all. After conducting a series of normality and homogeneity tests, it was concluded that the t-test was used for four tests and two-way ANAVA was used to test the interaction between open ended approach and prior ability to influence mathematical creative thinking skills. A summary of testing of the test of mathematical creative thinking skills with the help of Microsoft Excel, is presented in table 2 below.

TABle 2. Test Results of Mathematical Creative Thinking Ability

\begin{tabular}{|l|c|c|c|}
\hline \multirow{2}{*}{ Creative thinking ability } & \multicolumn{3}{|c|}{ Result } \\
\cline { 2 - 4 } & & & Conclusion \\
\hline High & 2,052 & 2,583 & Accept \\
\hline Low & 2,045 & 2,193 & Accept \\
\hline All & 2,002 & 3,299 & Accept \\
\hline
\end{tabular}

The test results in table 2 show that all $\mathrm{H} 1$ are accepted. That means that students' mathematical creative thinking skills who follow learning with an open ended approach are higher than those who follow learning with conventional approaches. This finding also applies to students with high, low, or total prior abilities. This is because the learning using an open ended approach gives students the opportunity to investigate various strategies and ways that they believe in accordance with the ability to elaborate the problem. Mustikasari [13] said that learning with open ended approach aims to make students' mathematical thinking abilities 
develop optimally and at the same time creative activities of each student are communicated through the teaching and learning process. Next, testing mathematical creative thinking ability using two-way ANAVA which is used to determine the interaction between open ended approach and prior ability to influence students' creative thinking ability. $\mathrm{Ft}$ 4.01 with $a=0.05$ greater than Fh 0.44 so accept H0. That is, there is no interaction between the open ended approach and the prior ability to influence students' creative thinking ability.

Based on the results of the study it can be seen that the influence of mathematical creative thinking abilities of students taught using the open ended approach is better than those of students who are taught using conventional approaches. This happens because learning through an open ended approach students are able to actively participate and are able to encourage students 'intellectual development, develop mathematical understanding and skills and develop students' desires to do mathematics, and also requires students to use various strategies and ways that are believed to be in accordance with the ability to elaborate the problems given . As stated by Suherman [14] that one aspect of the approach must be open. The point is that learning activities must accommodate students' opportunities to do everything they can to complete answers according to their will. In other words, learning with an open ended approach does not only look at the final results but how to get the answers. Students are given the opportunity to find their own answers and share their answers with their friends. This can foster the openness of students to accept differences of opinion from other students and can also foster self-confidence because students are involved in a learning atmosphere that provides flexibility to students as in learning with an open ended approach.

The open ended problem that was done in this study was about comparison. One example of the problem is that it is widely known that Pak Bambang's and Pak Razaq's fields are $\lceil 560 \mathrm{~m} \rrbracket \wedge 2$. Based on the area of the rice fields, students are asked to make several comparisons that show Mr. Bambang's rice fields wider than Pak Razaq's rice fields. So, students can freely determine for themselves the extent of Pak Bambang's and Pak Razaq's fields with the conditions of Pak Bambang's rice field wider than Pak Razaq's rice field. With the open ended problem, students can express their ideas in solving the problem correctly. This is evident from the answers of students who gave more than two problem solving. From these students' ideas, they have been able to improve creative thinking skills, Unlike the conventional approach in the control class which prioritizes the role of the teacher in the learning process. Learning uses a conventional approach that is students are given concepts and explained by the teacher directly through question and answer, but students are not given the opportunity to find their own concepts through activities that involve activities, so information given is still abstract for students. After the information is given by the teacher, students are given the opportunity to record, ask questions and do exercises or assignments. Based on the description of ditas, it can be seen the differences and improvement in the ability to test mathematical creative thinking of students in the experimental class and the control class. Where the best value of the experimental class students is higher than the control class. Conversely the lowest value obtained by the control class students after being treated using an open ended approach. Learning with an open ended approach gives students the opportunity to think freely to answer problems through various ways or strategies and develop them according to the knowledge and abilities possessed by each student because in every problem in open ended has more than one answer or solution so students can express the idea is to solve the problem correctly. This is evident from the answers of students who gave more than two problem solving with the open ended approach better than those using conventional approaches

\section{IV.CONCLUSION}

Based on the results of research and discussion it can be concluded that learning with an open ended approach gives a better influence than conventional approaches in improving students' creative thinking skills. This conclusion also applies to students with high, low, or total prior abilities. There is no interaction between learning with the open ended approach and the prior ability to influence students' creative thinking skills. Open ended approach is a learning approach that presents a problem that has more than one answer or method of completion so that this approach gives students the opportunity to gain knowledge, experience find, recognize and solve problems in several different ways.

\section{REFERENCES}

[1] Susanto. Ahmad, Teori Belajar Pembelajaran di Sekolah Dasar. Jakarta: Kencana Prenada Media Group, 2013.

[2] Filsaime. Dennis. K, Menguak Rahasia Berpikir Kritis dan Kreatif. Jakrta:Prestasi Pustaka, 2008.

[3] Munroe. Lloyd, "The Open-Ended Approach Framework”, European Journal of Educational Research,4(3),97-104, 2015.

[4] Inprasitha. Maitree, "Open-Ended Approach and Teacher Education", Tsukuba Journal of Educational Study in Mathematics.25, 169-177, 2006.

[5] Murni, "Open-Ended Approach in Learning to Improve Students ThinkingSkills in Banda Aceh", International Journal of Independent Research and Studies, 2(2), 95-101, 2013.

[6] Riyanti. Sri, "The Effect of Open-Ended Approach and Beliefs about Math Toward Students Mathematical Connection", Indonesian Journal of Educational Review, 2(2), 55-66, 2015.

[7] Fatah. Abdul dkk, "Open-Ended Approach: An Effort in Cultivating Students' Mathematical Creative Thinking Ability and Self-Esteem in Mathematics", Journal On Mathematics Education.7(1), 11-20, 2017.

[8] Irawan. Andi ., Edy. Surya, "Application of the Open Ended Approach to Mathematics Learning in the Sub-subject of Rectangular", International Journal of Sciences: Basic and Applied Research, Retried from https://www.researchgate.net/publication/318561142, 2017.

[9] Al-Absi. Mohammad, "The Effect of Open-ended Tasks -as an assessment tool- on Fourth Graders' Mathematics Achievement, and Assessing Students' Perspectives about it", Jordan Journal of Educational Sciences. 9(3), pp. 345-351, 2012.

[10] Viseu. Floriano., Ines Bernardo Oliveira, "Open-Ended Task in the Promotion of Classroom Communication in Mathematics", International Electronic Journal of Elementary Education, 4(2), 287300, 2012.

[11] Shimada. S ., Becker. J.P, The Open Ended Approach : A New ProposalFor Teaching Mathematics, Virginia : National Council Of Teacher Of Mathematics, 1997.

[12] Suherman. Dkk, Strategi Pembelajaran Kontenporer, Bandung :JICA,2001

[13] Mustikasari., Zulkardi Nyimas Aisyah.Pengembangan Soal-soal Open Ended Pokok Bahasan Bilangan Pecahan di Sekolah Menengah Pertama, (2010). $\quad 4(1) \quad$ Sumber dari (http://eprints.unsri.ac.id/843/1/5_Mustika_sari_45_60.pdf). 